\title{
限局性眼球白巟症を伴ったヒトおよび 白猫の先天性嚾聴
}

九州大学医学部耳鼻咽喉科学教室

营 文朗

はじぬに

遺伝性難聴の中には眼の異常を伴って発現するもの がありその種類は多㥞である。Konigsmark はよれ ばそれらは鞍鼻・近視・白内障を伴った優性遺伝によ る難聴, 近視・末梢神経障害。骨格異常を伴った優性 遺伝による難聴, 近視を伴った劣性遺伝による難聴, 網膜色素変性を伴った Usher 病233)，劣性遺伝による 失調性多発神経炎を伴った Refsum 病, 網膜変性・糖 尿病肥満症を伴った劣性遺伝によるAlström 病, 網膜 剝離・筋萎縮症・精神発育遅延を伴った劣性遺伝によ る難㯖, 視神経菱縮・若年性楉尿病を伴った難聴, 多 発性神経・視神経萎縮を伴った難聴, Waardenburg症 侯群 ${ }^{4)}$, 白览症に伴った優性遺伝による難聴, van der Hoeve病などに分類されている。

著者は青色紅彩をもった白猫の遺妘性難聴例につい て電気生理学的および病理組織学的観察を行っていた が，その後，日本人の中で青色紅彩を伴った先天性難 聴定数症例経験したので, 両者を比較検討し, 眼色調 異常を伴った先天性難㯖について考察を加えたい。

\section{観察}

ヒトト：症例は7才から19才までの5例で，いずれも 日本人次子であった。1例の父は的彩色調異常を伴わ ない先天ろらであった。他の 4 例では両親の血族結婚 や近親者のろらはみられなかった。染色体検査は1例 に施行されたが異常はなかった。

虹彩は 4例では両側とも同じように青色 (isochromia iridis) であった。ただ，7才の1例のみは左虹彩 は全体が青色, 右虹彩は 9 12時にかけて黒褐色で他 注青色 (unilateral partial heterochromia iridis) であっ た（図 1)。眼底検查では全例とも色素が少なく，白 子様であり, 限局性眼球白児症との診断であった。頭 髪はいずれも黒褐色であり，白髪はなかった。 heterochromia iridisのある7才の例では乘唇があり, 内眼 角閒距離はやや広く $37 \mathrm{~mm}$ 岕った。14才の1例では内
圈 1

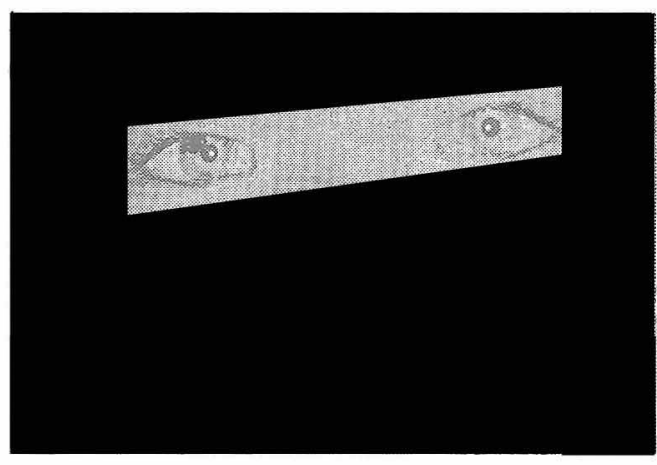

図 2

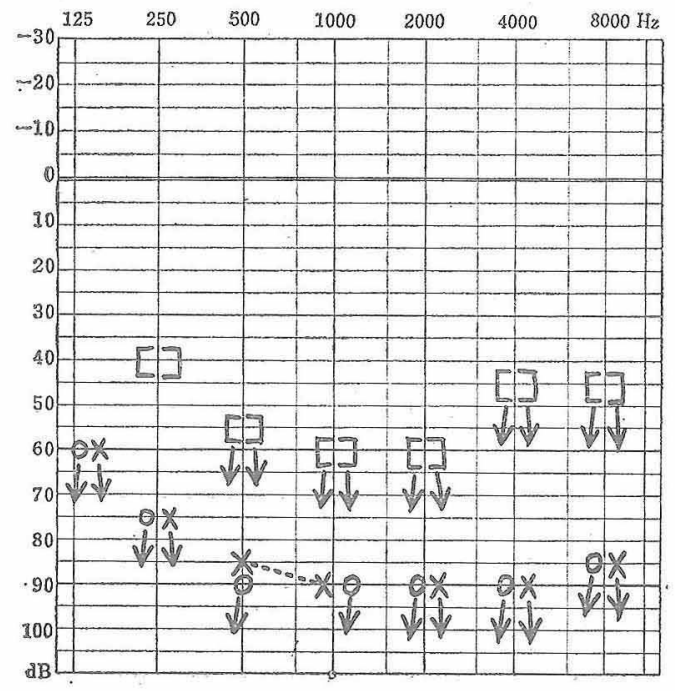

眼角間距離注 $35 \mathrm{~mm}$ でまったが，鼻根部恀幾分高めで あった。

純音聴力検査で端全らう汸 2 例, 亜全ろうが 3 例で 岕った。標淮型オージオメータの最大出力でも反応が 得られない例では時に $30 \mathrm{~dB}$ 増幅のブースタを用いて 聴力検查を行った。図 2 は前述の 7 才例のオージオグ ラムである。残聴があるものは低・中音域に多かっ た。語音は全例とも德取し得なかった。自発眼振およ 
び頭位眼振はなかった。calonc test では両側の canal paresıs が 4 例， 1 側のみの canal paresıs が1例であ った。平衡障害に対する視性代償機能は良好であっ た。これらの症例の詳細については既に報告したこと があるので省略する゙。

ネコ・7 匹の白猫について観察した。猫の聴覚は behavioral audiometryと誘発脳波によって判定した。 behavioral audiometry は防音室内で 125 8, 000 Hz 純 音について行い，Neff and Hind によって測定された 值6) を基凖として判定した。誘発脳波测定は塩酸ク口 ールプロマジン $25 \mathrm{mg} / \mathrm{Kg}$ と塩酸プロメサジン $25 \mathrm{mg} / \mathrm{Kg}$ を腹腔内に注射した状態で行った。測定電極は頭頂部 に，比較電極は耳介後部においた。検查音として 500 msec. 持続, $50 \mathrm{msec}$ rise decay time の $250 \sim 8,000 \mathrm{~Hz}$ tone pip 10 秒間隔で20回与え, 誘発媨波を EPUT アナログコンピュータにより加算平均し, 反応域值を 求めた。

7 匹の中の 4 匹では behavioral audiometry でも， 誘発脳波測定によっても，その域値は Neff and Hind の報告した域值に較べてとの周波数でもほぼ $30 \mathrm{~dB}$ 以 内にあった。この 4 匹は正常群とした。他の 3 匹では behavioral audiometryでも, 誘発脳波でもその反忘域 值は著しく上昇していた。この 3 匹はろらとみなし た。この群の中の 1 匹は両側虹彩が青色の成熟牡猫, 他の 2 匹親子の牝猫で，いずれも右虹彩が青色で左 虹彩は淡緑褐色であった。子猫柱生後 9 力月であっ
た。図 3 は $95 \mathrm{~dB}$ および $105 \mathrm{~dB}$ SPL の $1,000 \mathrm{~Hz}$ tone psp に対する正常白猫とろ 5 白猫の誘発加算脳波を示 す。図の左列は正常猫で明瞭な反応がみられるが，右 列のろら猫ではこの音圧でも反応がみられない。

次に，ネンブタール麻酔下に中耳骨胞を開放し, 蝸 牛空膜にあてた電極から螖牛マイクロホン電位, summating potentıal および聴神経活動電位を測定した。 前 2 者の測定には500 10,000 Hz tone pip を, 後者の 测定には click を用いた。 $10 \mu \mathrm{V}$ peak-to-peak の蝸牛 マイクロホン電位が測定されるための $2,000 \sim 8,000 \mathrm{~Hz}$ の検查音の音圧は正常群では 0〜20dB SPL であった が，ろう群では $100 \mathrm{~dB}$ の音に対しても痕跡的にしか蝸 牛マイクロホン電位や summating potential が測定さ れなかった。㯖神経活動電位についても同様で，正常 群では70dB SPL の clck によって明瞭な活動電位が 測定されたが，ろら群では全く反応がみられなかっ た。図4の左例は正常猫で測定された蜈牛マイクロホ ン電位 $(\mathrm{CM})$, summatıng potentıal (SP) および聴神 経活動電位 (AP) である。本例では正電位を上方へ， 負電位を下方へ向からように記録した。従って, 聴神 経活動電位の $\mathrm{N}_{1}, \mathrm{~N}_{2}$ は下方への spike としてみられ る。また， summating potentralをより明瞭に現わすた めに記録に low pass filter $(06 \sim 600 \mathrm{~Hz})$ を用いたの で，高音域の検査音に対する蛊牛マイクロホン電位は 実際よりも小さく記録されている。図 4 の右列はろ 猫での測定で, 蝸牛マイクロホン電位, summating

\section{CORTICAL EVOKED POTENTIAL}

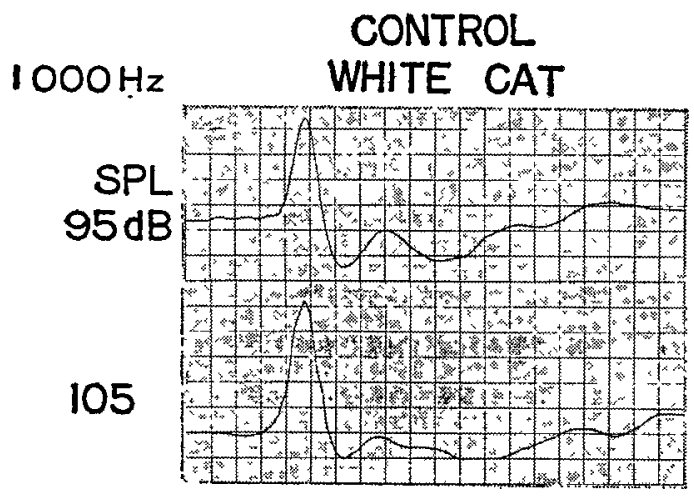

HEREDITARY DEAF WHITE CAT

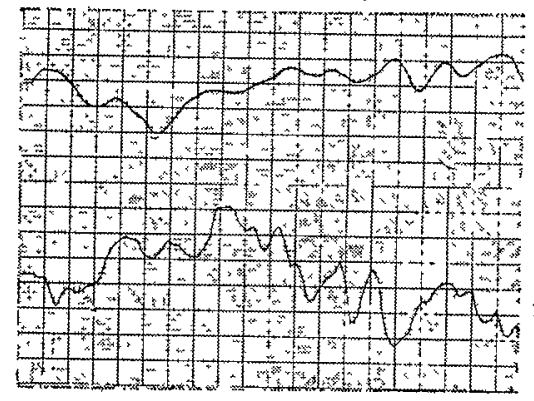

$100 \mathrm{msec} \mathrm{L}$

\section{SUMMED RESPONSE TO 20 TONE PULSES}


図 4

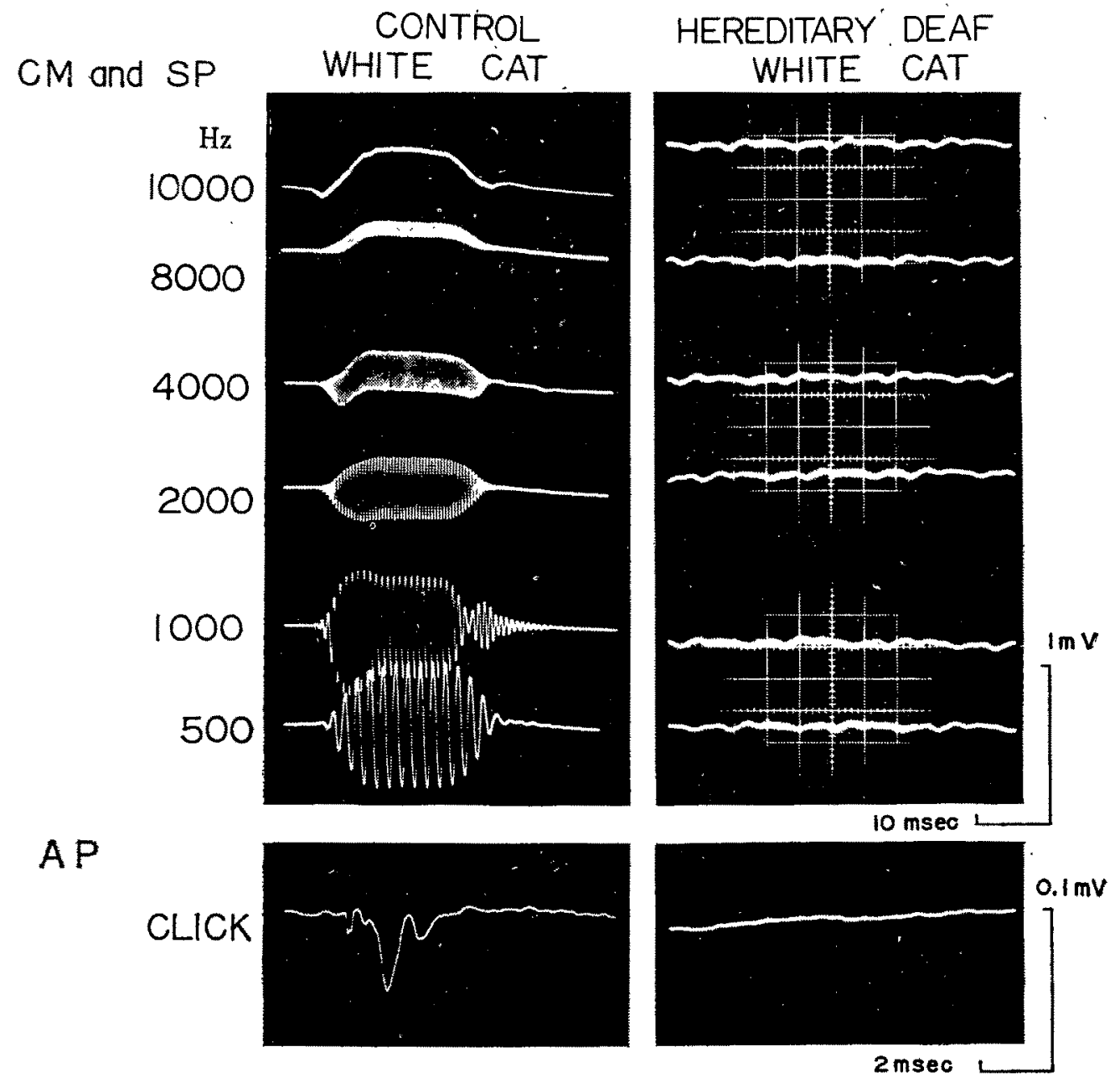

\section{(0.6-600 cps PASS FILTER )}

potential，㯖神経活動電位はいずれも記録されなかっ た。ただ,ららと思われていた生後 9 カ月の牝猫では 青色虹彩と同側の右耳電位が測定されなかったが， 淡緑褐色の红彩と同側の左耳には正常な電位がみられ た。この例では組織学的検查でも異常は右耳のみにみ られ，左耳は正常であった。すなわち，青色虹彩と同 側の一側性難㯖であると思われた。この問題について は既に記載したことがあるので詳しくは述へない゙。

これらの観察に続いて, $3 \mathrm{~mol} \mathrm{KCl}$ 溶液をみたした ガラス毛細管微小電極を用いて螖牛内の静止直流電位 を測定した。蝸牛空から蝸牛管へ向加って微小電極を
刺入して行くと, 正常猫の基底膜で纹負の静步電位 が, 蝸牛管では正の静止電位が測定された。微小電極 の大きさや刺入速度などによって, 基底膜の負電位に は相当大きなばらつきがみ,られたが, 螖牛管内の正電 位の大きさはどの例でむほぼー定で $80 \sim 90 \mathrm{mV}$ 程度で あった。ろら猫ではいずれの例でも基底膜の負電位は 測定されたが，さらに電極を進めても正電位江測定さ れなかった。

電気生理学的測定を終った動物は生理食塩水で生体 灌流後, 10\%ホルマリンで固定した。摘出した内耳注 EDTAで脱灰し，18 $\mu$ の厚さの切片を作製，一マトキ 
シリン・エオジン染色後，光学䫓微鏡で観察した。

蜩牛電位が測定されなかった内耳にはずれも Scheibe 型の蛼牛。球形靠変性がタられた。すなわち， 血管条杜著しく萎縮してほとんど認められず，ラセン 器はその形をとどめていなかった。蔁膜は丸くなり， 一層の上皮で得われた個所が多った。ライスネル膜は 血管条壁や基底膜に接着し，螖牛管は者しく虚脱して おり，全く消失している回転も交った。外ラセン溝細 胞に注胞性変性がみられた。これらの異常は蝸牛の 全回転にわたってみられた。ラセン神経節にも萎縮が 著しかったが，それは基底回転側で特に強かった。た だ，生後 9 カ月の若いろう猫のみはラセン神経節の萎 縮が比較的軽度であった。

图 5 は万ら白猫の蝸牛基底回転走示す。この例では ライスネル膜は基底膜に完全に接着し，螖牛管腔は消 失しており，血管条やラセン器はみられない。蓋膜は 巻き込まれているよらにみえる。ラセン神経節の萎縮 は著しく，ごく少数の神経節細胞が存在しているにす ぎない。

前庭・半規管での異常は球形孁の虚脱と球形囊玟の 変性であった。光学影微鏡下では卵形襄や半規管には

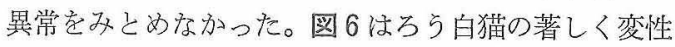

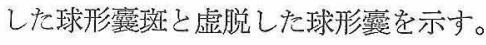

これらろら白猫の内耳のメラニン色素について詳細

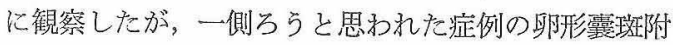
近と半䂓管膨大部に少量の黑色色素がみられた他には 存在しなかった。

\section{济揬}

青色出彩をもったろら白䖪の内耳病变は典型的な Scheibe 型の cochleo-saccular degeneration だある。 病理組織学的にはラセン器の変性が著しく，ラセン神 経節にも彩縮がみられ，また蛸牛マイク口ホン電位や 聴神経活動電位も痕跡的にしか測定されないので, 蜡 牛に著しい機能障害が生じていることがわかる。私共 の得た新しい発見はこの型の障害のある内耳では螖牛 管に存在す心゙き正の静止電位が消失していること老知 ったことである。図 5 のごとく蝸牛管の虚脱が著し く，ライスネル膜が基底膜に需着して内リンパ腔が消 失している例では勿論のことであるが，電位測定後の 組織検查で蚎牛管が大きさ澸少していてすなお存在 していることが確かめられた例でも，螖牛管腔内で正 の静止電位は測定されなかった。このことは Scheibe 型の cochleo-saccular degeneration では蜗牛管内の液
図 5

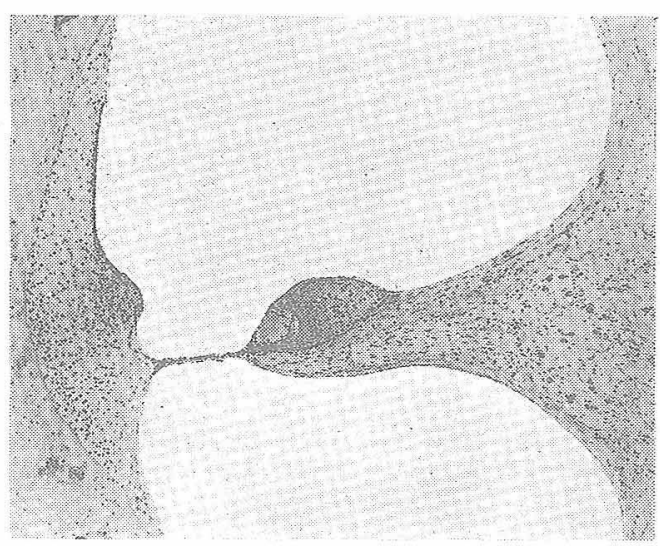

娄 6

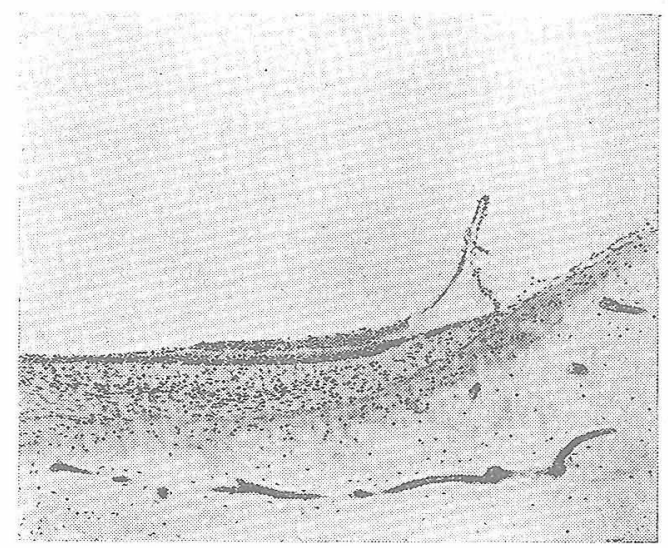

は内リンパとしての特有なイオン組成孛失っており， 恐らく外リンパと同様の組成となっていることを示唆 しているといえよう。この型の内耳障害は血管系の菱 縮によって生じた内耳液生産機能の低下によるものと 一般に理解されている。しかし，杉浦はHedlund る ら白色ミンクの cochleo-saccular degeneration で球形

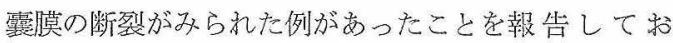
りここの部よりの内リンパ漏出も原因の一つとしてい

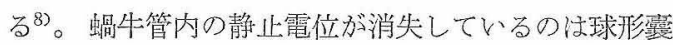
部に祃ける内。外リンパの短絡によるものであるかも 知孔ない。

ヒトに拐をこの種の難聴例の病理組織学的観察は 極めて之しい。気管支肺㷋によって死亡した 子の Waardenburg 症候群症例吕 Fisch によって報告 されており，コルチ器の消失，血管条とラセン神経節 の菱縮が観察されている9。前庭，半規管には異常が なかったと記されている。 
Lindeman による Waardenburg 症候群の1例では cochleo-saccular malformation と思われたと述べられ ている10)。Fisch による記載がろ5白猫の病理組織学 的所見と相違する点は球形襄についてであるが，前庭 部の顕微鏡写真が揭载されていないので何とも判断で きない。さらに, Fisch の報告の写真ではライスネル 膜の状態がはっきりせず，文中にす記述がないので不 明であるが, 他の構造の変化からみて, 蛤牛管は強く 虚脱，ライスネル膜は基底膜や血管条に完全に接着し ている可能性が充分に考えられる。恐らく, ヒトにお けるこの型の難聴ではろう白猫と同様な内耳病変がお こっているのではあるまいか。

Scheibe 型の内耳障害は先天性の 発育障害によるも のではなく，一旦完成した内耳がその後に何らかの原 因で変性に陥入ったものと理解されている。Bosherに よれば遺伝性難㯖の白猫の内耳病変恃生後 5 日目から 認められるようになり，生後21日目までには完了する 急速な変性であるとされている11。ヒ小の限局性眼球 白児症を伴った難聴が白猫の内耳障害と類似した病変 によるものとすれば，それは実は先天性難㯖しいうよ り注, 先天性に素因があり出生後に発現する障害であ るのかむ知れない。もしもそらであるとすれば,フェ ニールケトン尿症の脳障害が防止できるように，将 来, このよらな難聴の発現を防止できるようになるこ とも，あながち夢ではあるまい。

次に, 前庭障害についてふれたい。限局性眼球白児 症を伴った先天ろうのヒト 5 症例の中で 5 例 9 耳は canal paresisであった。万弓白猫では caloric test は 施行しなかったが，光学顕微鏡による病理組織検查で

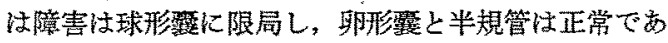
るよらにみえた。もしも，ヒトと白猫にみられるこの 型の内耳障害が類似したものであるとすれば，半規管

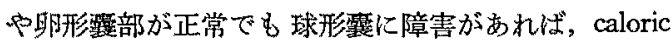
test で canal paresis として現われるということにな る。caloric test は半規管の機能検査であると漠然と理 解していたが，その考えに修正を加えるべきなのかる 知れない。あるいは光学顕微鏡の level では観察し得 ない変化が半規管部に存在していると理解すべきかむ 知れない。または杉浦の指摘した球形蘘膜の断裂8》の 有無が caloric test の成續を左右しているのかもわか らない。cochleo-saccular type の内耳障害が推測され る遗伝性難聴の中には caloric test で正常反応が得ら れる例とそらでない例とがある。一口に Scheibe 型の cochleo-saccular degeneration といっても, 今後さらに
紐かく分類されて行くべきものではないだるらか。

限局性眼球白児症を伴ったヒトの先天万う 5 症例の 中で，低音域において気導と骨導聴力の域値に著しい 差があったものが 2 例 4 耳あった。その 1 例は右耳で は $250 \mathrm{~Hz}$ で $65 \mathrm{~dB}, 500 \mathrm{~Hz}$ で $50 \mathrm{~dB}$, 左耳では $250 \mathrm{~Hz}$ で $50 \mathrm{~dB}, 500 \mathrm{~Hz}$ で $35 \mathrm{~dB}, 1,000 \mathrm{~Hz}$ で $40 \mathrm{~dB}$ の air-bone gap があった。また，他の 1 例で注 $250 \mathrm{~Hz}$ で両耳と $35 \mathrm{~dB}$ 以上の air-bone gap があった。勿論, これらの例の 鼓膜所見には異常がなかった。

感音性難聴症例においてしばしば経験する低音域に おけるこのような大きな air-bone gap は一般に骨導. の vibrotactile なものによるとする説と vestibular hearing によるものよする説の二つによって説明され ている。後者で注特に球形摆斑の衔きが重要視されて いる。ヒ卜の症例の内耳病変が Scheibe 型の cochleosaccular degeneration であると仮定するならば, 低音 域化括讨る良好な骨導聴力は vestibular hearing, 特に 球形囊斑の働きによるものとする説は受け入れ難くな る。吻諭，骨導㯖力梳皮下組織の厚さや外・中耳の形 態の個人差によっても左右されよう。著者は高度な感 音性難聴に打ける低音域骨導聴力の良し悪しはラセン 神経の菱縮の程度とも関係があるのではないかと考え ているが，この問題は本文の目的からはずれるので他 の機会にゆずりたい。

白猫にみられる難䏇は Bosher らの研究によると優 性遗伝によるむのとされている。難聴の遭伝性の penetrance はしかしながらおよそ80\%にすぎないとされ ている11)。ヒトにみられる Waardenburg 症侯群も常 染色体性の優性遺伝であるとされている”。

他方, 日本人のこの種の難聴については少々栏子が 異って扔り，遺伝関倸の認められなかった症例が数多 く報告されている。小倉によるWaardenburg 症候群 の 3 症(例 ${ }^{(2)}$ や, 岡本 ${ }^{13)}$, 熊本 ${ }^{14)}$, 東城 ${ }^{15)}$, . 永谷 ${ }^{16)}$, 松 本 ${ }^{17}$ によって報告された heterochromia iridis を伴っ た先天性難聴症例ではいずれる遗伝関係が認められて いない。また, 楠原 ${ }^{183}$, 松畸 ${ }^{193}$, 生駒 ${ }^{203}$ にっって報告 された isochromia iridis の青色虹彩を伴った先天性難 聴症例でも近親者に難聴が発見されていない。生駒は 突然変異によるものであるうと推論している。本論文 のヒト 5 症例の゙中で近親者に難㯖があったのは 1 例の みであり，他の 4 例には遺伝関係を立証する手がかり は得られなかった。従って、これが遺伝性疾患である としても，劣性遗伝によるものと考えたかがより、妥当 であるう。限局性眼球白児症を伴ったヒトと白猫の先 
天性難聴の遺伝様式は異なっているようであるが，そ の病変には類似点が多く，この種の動物の観察がヒト の先天性難聴の病態を解明して行くらえで重要な手が かりとなろう。

$$
\text { 結語 }
$$

ヒトにみられた限局性眼球白児症を伴った先天性難 聴 5 例の臨床的観察と青色虹彩をもった白猫の先天性 難聴 3 例の病態生理学的および病組織学的観察とを比 較検討した。万ら白猫の病変は Scheibe 型の cochleosaccular degeneration であり，ヒトの症例にも同様な 障害がおこっていると思われることを過去の文献から 考察した。猫の蝸牛内静止電位を測定した結果, この 型の内耳障害は内リンパの異常に基くものであること を電気生理学的に証明した。ヒト症例の大部分には canal paresis があったが，万う白猫の半規管々卵形票 には形態的な異常がみられず，この矛盾は今後の課題 として残された。

本研究に御協力下さった鬼木信乃夫先生, 大野新治 先生, 田原睦郎先生, 宮本成章先生, 永吉実光先生お よび Karl W. Hattler, Ph. D. に感謝する。

本文の一部は第16回日本オージオロジー学会 総会 （1971年 9 月15日）に抒いて発表した。

\section{Partial Albinism of the Eye and Congenital Deafness in Man and White Cats}

By

Fumiro Suga, M.D.

Department of Otorhinolaryngology, Faculty of Medicine, Kyushu University, Fukuoka, Japan

Comparative studies of congenitally deaf human and white cats with partial albinism of the eyeball were made. Pathology of inner ear lesion in man was explained by electrophysiological and histopathological data obtained from the deaf white cat. Absence of the endocochlear resting potential in the deaf white cat indicated an ionic alternation of endolymph. A cochleo-saccular degeneration of Scheibe's type which observed in the white cat may be produced by this ionic change. Cochlear lesion in the deaf human was attributed to the same pathology. Majority of the human cases had canal paresis while the histopathologic observation of the deaf white cat demonstrated nor- mal structures of the semicircular canals and the utricle. Reasons of this discrepancy have not been explained. Inheritance of deafness in the white cat was a dominant autosomal mode while majority of the human cases did not show the dominant inheritance.

\section{文献}

1). Konigsmark, B.W.: Hereditary deafness in man. New Engl. Jour. Med., 281 ; 713, 774, 827, 1969.

2) Usher, C.H.: On the inheritance of retinitis pigmentosa, with note of cases. Royal London Ophthal. Hosp. Reports, 19 ; 130, 1914.

3 ）菅 文朗, 他：網膜色素変性, 白点状網膜炎を伴 った先天性難㯖。耳鼻, 18 ; 印刷中。

4) Waardenburg, P.J.: A new syndrome combining developmental anomalies of the eyelids, eyebrows and nose root with pigmentary defects of the iris and head hair and with congenital deafness. Amer. J. Hum. Genet., 3 ; 195, 1951.

5 ）菅 文朗，他：虹彩色調異常を伴った先天性難 聴。耳鼻, $18 ; 83,1972$.

6) Neff, W.D. and Hind, J.E.: Auditory threshold of the cat. J. Acoust. Soc. Amer., $27 ; 480,1955$.

7) Suga, F. et al: Physiological and histopathological correlates of hereditary deafness in animals. Laryn. goscope, $80 ; 80,1970$.

8 ）杉浦昭義 : Hedlund 白色ミンクにおける螖牛・球 形垔变性。Audiology Japan, 12；431, 1969.

9) Fisch, L.: Deafness as part of an hereditary syndrome. J. Laryng., 73 ; 355, 1959.

10) Lindeman, R.C.: Congenital sensorineural deafness. Sensorineural hearing processes and disorders. p. 451, Little, Brown and Co., Boston, 1967.

11) Bosher, S.K. et al: Degenerative process in deaf white cat: Possible relationship to unexplained human congenital deafness. Sensorineural hearing processes and disorders. p. 381, Little, Brown and Co., Boston, 1967.

12）小倉義郎，他：遺伝関係を認めぬ Waardenburg 症候群の 3 症例。耳鼻臨床, $61 ； 1082,1968$.

13) 岡本晴一：虹彩異彩症 (Heterochromie der Iris)

の数例。中眼, $13 ; 604,1922$.

14）熊本秀雄：先天性虹彩異色症(所謂金銀眼)。日眼, 
$38 ; 1630,1934$.

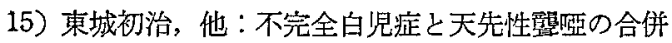
症例。日眼紀, $9 ; 44,1958$.

16) 永谷 䨓：乳彩異色および網膜色素欠損症を合併

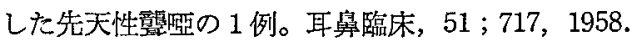
17）松本勝男，他：先天性虹彩異色（いわ他る金銀 眼）と合併した片側整の 1 例。耳喉, 33；23，1961.

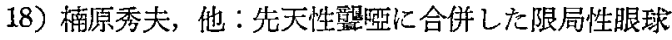
白児の1例。眼臨, $45 ; 681,1951$.

19）松崎 力, 他: 限局性眼球白児症に先天繁が合併 した症例。日耳鼻, $68 ； 618 ， 1965$.

20）生駒尚秋，他：虹彩色素異常を伴った先天性万弓 蕣の 1 例。耳鼻臨床，62；271，1969.

（受付 47.4.4） 